\title{
LEARNER-CENTERED TEACHING: WHAT MAKES IT EFFECTIVE
}

\author{
Endang Darsih \\ Department of English Education, Faculty of Teacher Training and Education, Universitas Kuningan \\ E-mail: endangdarsih@gmail.com
}

APA Citation: Darsih, E. (2018). Learner-centered learning: What makes it effective. Indonesian EFL Journal, 4(1), 33-42. DOI: 10.25134/ieflj.v4i1.796.

Published: 01-01-2018

\begin{abstract}
Learner-centered teaching is a teaching approach that is increasingly being encouraged in education. In Indonesia, learner-centered teaching has been an obligation for teachers to be implemented since the government decided to try out the new designed curriculum, the 2013 curriculum. However, it is not always effective since teachers are lack of creativity, lack of responsibility and knowledge. Therefore, this study was sought to find out teacher's efforts and their roles in implementing learner-centered teaching effectively. The study involving two English teachers revealed that several efforts done by teachers in learner-centered teaching are; 1) let the students do the hard messy work of learning because they are not passive recipients of knowledge, 2) give autonomy and responsibility to students for material they learn and their own learning in general, 3) use highly engaging core content that meets the needs of the students, 4) give feedback to help students to improve, and 4) utilize multiple teaching techniques appropriate for student learning goals. Several roles of teachers in learner-centered teaching are as guides, facilitator and coaches. Teachers also play important roles in creating an environment that fosters students' learning, accommodates different learning styles, and motivates students to accept responsibility for learning.
\end{abstract}

Keywords: Learner-centered teaching, teaching approach, teachers' efforts \& roles

\section{INTRODUCTION}

Learner-centered teaching is an approach to teaching that is increasingly being encouraged in education. Learner-centered teachers do not employ a single teaching method. This approach emphasizes a variety of different types of methods that shifts the role of the teachers from givers of information to facilitators in student learning.

Traditionally, teachers focused on what they did, and not on what the students are learning. This emphasis on what teachers do often leads to students who are passive and who did not take responsibility for their own learning. Educators call this traditional method, "teacher-centered teaching." In contrast, "learner-centered teaching" occurs when teachers focus on student learning.

In Indonesia, learner-centered teaching has been popular since the government decided to try out the new designed curriculum, the 2013 curriculum. Thousands of schools, ranging from elementary (SD), junior high (SMP), and senior high (SMA) have participated in this try out. This curriculum was officially launched on July 15 starting with first, fourth, seventh and tenth graders and the very reason to justify such implementation of the new curriculum is because the ministry wants to restore character education and improve students' creative thinking. In the 2013 curriculum, it is a must for every teacher to apply learner-centered teaching. It should be able to give space for students to learn the material based on their needs, interests, ability and their learning styles.

Learner-centered teaching is a broad educational concept that originated in fundamental changes in thinking about curriculum planning and pedagogy in the 1970s and 1980s (Nunan, 1988 in Benson, 2003). These are best summed up in terms of a shift in the focus of language education 
research and practice from language and linguistics to language learners and language learning that began in the 1960s with the development of psycholinguistics and sociolinguistics' and continued through the 1970s and 1980s with the establishment of "second language acquisition" as the key research concept in the field (Ellis, 1994).

Learner-centered teaching is an approach in which students have control over the learning process. With the learner-centered approach, teachers function as facilitators of learning rather than lecturers. In this way, teachers do less telling; students do more discovering. The roles of the teacher in the learner-centered approach are to design the course such that it creates a climate for an optimal learning; model the appropriate expected behavior for the students; encourage students to learn from and with each other; and provide more feedback throughout the process. Learner-centered teaching forces students to play an active role in their education, as opposed to the more passive role traditionally used. In other disciplines, the learner-centered approach promoted more in-depth learning and facilitated students' development into independent learners.

In line with that, Brown (2001) stated that learner-centered teaching includes: 1) techniques that focus on or account for learners' needs, styles, and goals; 2) techniques that give some control to the students; 3 ) curricula that include the consultation and input of students and that do not presuppose objectives in advance; 4) techniques that allow for students creativity and innovation, and 5) techniques that enhance a student's sense of competence and self-worth.

However, in some pilot project schools of the 2013 curriculum in Kuningan, West Java especially those located in remote areas and those with under-prepared students, it is not working effectively. It is seen from several facts gotten from the interview results with students. First is lack of teachers' responsibility. Some teachers just come to the class and give some topics to be discussed then leave the class shortly after that and come back when it finished. It sounds painful since teachers still translate learner-centered teaching as learning method without teacher. Though students are capable enough in doing that activity, ideal teachers should be in class to help, guide and facilitate their students. Second is lack of students' motivation. Perhaps, this is the most important variable to be paid attention in learner-centered teaching. Non-motivated students tend to be failed to be engaged in classroom activity. It happened in one of junior high schools in a remote area in Kuningan where the teacher is creative enough to create environment that fosters students learning, yet it is not working; as the result, teacher is busy to prepare students to study which is time consuming and still utilize the spoon-feed principle. Regarding the active participation in the class, the prepared and motivated students become more active and non-motivated students were still passive and rely heavily on teachers.

Some previous studies on learnercentered teaching are taken in this study. One of the studies was conducted by Tudor (1993) focusing on teacher's role in learner-centered classroom. Tudor (1993) stated that there would seem to be two main roles which teachers perform in most traditional modes of teaching. The first is that of knower; the teacher is a source of knowledge in terms of both the target language and the choice of methodology. In other words, the teacher is a figure of authority who decides on what should be learned and how this should best be learned. The second role is that of activity organizer: the teacher sets up and steers learning activities in the right direction, motivates and encourages students, and provides authoritative feedback on students' performance. Both of these roles will persist in a learner-centered approach, but teachers will need to assume a further role, that of learning counselor.

The second study was conducted by Thanh (2010) with the title implementing a student-centered learning approach at Vietnamese higher education institutions: Barriers under layers of Casual layered Analysis (CLA). The study revealed that the 
four layers of CLA help disclose weaknesses in the current traditional learning approach, causes that create the problems and hidden beliefs that keep traditional perceptions about learning permanent. Changing the students' present learning approach to studentscenteredness does not need a new collection of principles to be imposed on learners. Rather, there need to be changes in both school infrastructures and people's perceptions.

The last study entitled 'Effect of Learner-Centered Teaching on Motivation and Learning Strategies in a Third-Year Pharmacotherapy Course' was conducted by Cheang (2009). The objective of this study was to develop, implement, and assess a learnercentered approach to teaching a third-year pharmacotherapy course in a doctor of pharmacy (PharmD) program. As the main instrument, The Motivated Strategies for Learning Questionnaire (MSLQ) was administered to students before and after taking the course. The study revealed that the learner-centered approach was effective in promoting several domains of motivation and learning strategies in a third-year pharmacotherapy course. Students' intrinsic goal orientation control of learning beliefs, self-efficacy, critical thinking, and metacognitive self-regulation improved after taking the course. Students responded positively to the learner-centered approach. Additionally, students with a clinical practice career orientation or who prepared frequently for classes scored higher on several MSLQ domains.

Considering the explanation above, therefore, the writer has investigated two junior high schools in Kuningan. This study was sought to do the following: 1) to find out teacher's efforts in implementing learnercentered teaching effectively, and 2) to find out teacher's role in learner-centered teaching.

\section{METHOD}

The research applied a qualitative design because it investigates a phenomenon which is described by Cresswell (1994) as an approach which inquires often makes knowledge claims based primarily on constructivist perspectives. The researcher physically goes to the people, setting, site or institution to interview or record in its natural setting.

The research was conducted in two junior high schools in Kuningan because these schools are implementing learner-centered teaching. Two English teachers regarded as the sample of this study. The reason in choosing these teachers as the research sample based on students and other teacher's report that they are good at conducting learner-centered teaching.

In collecting the data, the research used two instruments. They were observation and interview. Marshall and Rossman (1989) define observation as the systematic description of events, behaviors, and artifacts in the social setting chosen for study.

Observations enable the researcher to describe existing situations using the five senses, providing a "written photograph" of the situation under study. The research used Learner-Centered Rubric for Classroom Observations based on Weimer (2013). The interview format used was open-ended questions which allow the respondents to give totally free answers. Two English teachers were interviewed by using Indonesian and English. They were asked several questions related to the learner-centered teaching.

Observation and interview were administered at the same time; on the tenth of November 2016. Classroom observation was conducted in a seventh class consisting of 31 students. It aimed at finding out efforts done by the teachers in implementing learnercentered teaching effectively. Moreover, the data of interview was then transcribed. Most of the interviews were conducted in English.

Nevertheless there were a number of occasions whereby Indonesian was used as the respective respondents felt more comfortable using the language. The data taken from observation and interview were then analyzed qualitatively. Since the topic is about learner-centered teaching, so the focus of analysis is on its components. The writer also analyzed the teachers' efforts and roles in learner-centered teaching. 


\section{RESULTS AND DISCUSSION}

The first part done in this study is investigating the teachers' efforts in implementing learner-centered teaching. Learner-Centered Rubric for Classroom Observations based on Weimer (2013) was used in this study. The learner-centered rubric for observations focused on five 5 practices that need to change to achieve learning centered teaching, namely: 1) The functions of content, 2) The role of the teacher, 3) The responsibility for learning, 4) The processes and purposes of evaluation, and 5) The balance of power. This study also employed interview to collect the data. The interview data were obtained from two respondents who were chosen based on purposive sampling. They were chosen in order to give detail information dealing with learner-centered teaching. In addition, they come from different schools and it is expected that they could present their various understanding and experiences of learner-centered teaching. The findings from the observation and interview are explained in the following subheadings.

\section{Teachers' efforts in implementing learner- centered teaching effectively}

Having observing the two English teachers, it is true that they have been implementing learner-centered teaching effectively. It is seen from the observation sheet that the activities and efforts done by the teachers belong to learner-centered category. Some facts supporting this condition are first, in the classroom the teachers are not a conveyor of information. It is the students who do the hard messy work of learning, they are not passive recipients of knowledge. Teachers gave feedback, and work to support and enhance to students investigation. They also welcome the questions and make an effort to redirect to the class so that other students answer questions rather than the teacher. They call on students, add detail to students' answers, offer the examples, organize the content, do the preview and the review. Learner centered teaching is one of the characteristics of the 2013 curriculum as stated in government regulation number $81 \mathrm{~A}$ about the 2013 Curriculum Implementation. This finding is line with what has been stated in this document that the passive learning pattern becomes active-looking learning where active student learning seeks to be reinforced by the learning model of the scientific approach. Learner centered teaching becomes a compulsory approach to teaching in the 2013 curriculum that prioritizes students' interests and abilities in learning. Learner centered teaching should provide space for students to learn according to their interests, personal abilities, and learning styles. Students are naturally different from each other either in their interest in a teaching material, their respective intellectual abilities or in their preferred learning style. As we know that the intellectual ability of each student is different. Some students can learn independently by listening, reading, seeing, watching videos, following specific demonstration skills and so on without the help of others, but other students need to interact or collaborate with other learning environments such as with their friends, teachers, classroom environment, school and even need to work together in a working group. Some others need to play a bit with challenges and so on. That is why, in the learner-centered teaching, teachers need to provide a variety of mediums and approaches in cooperative learning or group work, not as a conveyor of information or the only source of learning.

Second, the teachers do not overwhelm the students with a large amount of content. Content functions as a vehicle for skill development. During the teaching and learning process, both teachers help students learn how to ask good questions, how to read effectively, how to critically analyze information, how to write, how to study, how to summarize information, and how to work effectively in groups. Content is not the only responsibility of the teachers, in fact the teachers need to enable students to learn effectively, she/he must make the condition where there is a process of interaction between learners with teachers, learners with learning resources and 
media, and also learners with learners. The main medium for the interaction to occur is the question, the observation activity, or the problem to be solved by student-centered learning. Teachers need to believe that students are individuals who have the seeds of knowledge in them that requires various activities to develop it into a meaningful understanding of something. In view of this 2013 curriculum learning, students need and must be involved in constructing understanding through reasoning by themselves or in group discussion that discusses a learning material. Teachers are more of a facilitator in the process of building that knowledge, not to overwhelm the students with a large amount of content or material. Therefore, there should be activities that students need to build their own knowledge from various learning sources.

Third, teachers are patient, caring, and know all or most students by name. The teacher listens carefully to students. The teacher treats students fairly and consistently. In other words, no one gets "special treatment," there is consistency between what the teacher says and what he/she does. Students have different characteristics regarding physical, intellectual, socialemotional, moral, spiritual and cultural background. Teachers should take notes on students' characteristics to help them learn optimally. It is actually one of the forms of teacher's caring of their students. Teachers should have a broad insight into personality dimension and its implications in educational goals because the essence of education is to form the personality of learners that are intact and balanced. So, a narrow-minded teacher can have a negative impact on the achievement of educational goals. For example, excessive emphasis on the cognitive aspect will lead to an intellectualistic, unskilled, and low-morality education. Thus, the teacher in dealing with tasks and roles should always try to balance and integrate the personality of the learner dimensions to become a human personality intact and balanced. This is very important, considering the tendency of learners in actualizing their potentials will determine the style of personality in the future. The attitude of teachers to the tasks of education is very necessary because in the implementation of the learning process in practice tend to be transactional and situational. This means not all aspects of education can be planned, and what happens in practice does not always fit with the planned before, especially the problem of classroom atmosphere. Therefore, in different situations, conditions and opportunities, teachers must apply their abilities differently according to the objectives, materials, media availability, the characteristics of learners, and situational conditions. So, the flexibility in the implementation of learning programs, wisdom in making decisions, and wisdom in taking action is necessary. Patience can be had when the teacher has emotional stability as an adult personality trait. Teachers whose emotions are stable will not be easily angered and will not be rash or careless in all his actions. Many instances in school are easy to ignite teacher anger. However, a teacher who has had emotional stability will remain patient and wise in facing these irritating events. Patience is very closely related to the attitude of caution. The impact for teachers will have noble traits and attitudes such as loving the students, diligent and tenacious in teaching them, understand the student's personality, understand the situation and conditions, so that in all his actions are not emotional, teachers are also sincere, polite in behaving, not easily angry and not easily feel offended. All attitudes and attributes associated with the teacher's patience attitude are very influential on the formation of student personality as expected in the purpose of education. Besides, almost all students put effort into the class, for example they arrive on time, they are not on their computers or cell phones during the class, they participate in class when asked. If some students choose not to put in effort, the teacher is aware and takes action to engage them. It sounds simple, but it gives significant impact on students' learning process. 
The last effort is teachers come up with ways to use evaluation to promote learning. Self assessment and peer assessment should be promoted. During class, teachers also use various formative assessment techniques such as group work and act on those assessments to improve students' learning. The implementation of a scientific approach in the 2013 Curriculum which involves observing, questioning, exploring, reasoning and communicating is also expected to transform the learning climate into a more active, collaborative, participatory, and stimulating ability to stimulate students' critical and analytical thinking skills, produce a work. In other words, learning is expected to be at a higher level in both the cognitive, affective, and psychomotor aspects. Learning activities are also expected to be collaboratively designed to train cooperation, communication skills, argumentative skills, and emotional control skills. Thus, in addition to learning the subject matter, the students were given the education of character and literacy as it is currently mandated by The Ministry of Education where the two things should be integrated in the learning activities. Regarding assessment, the respondents believe that assessment techniques measuring higher order thinking skill are also used so the students are not only able to know, understand and implement, but also to analyze and evaluate. It is not an easy job to design such higher order thinking test, therefore scientific forums such as training, workshops, or activities at MGMP or teachers association become a very strategic means to help teachers. In these activities, the teachers not only gain new insights from experts, but also can discuss the practice of applying higher order thinking skill learning and assessment. Self assessment is also used to match students' self-perceptions with reality. The results of self-assessment of students' perceptions are used as the basis of teachers for further guidance and motivation.

Interview with the two English teachers revealed several finding about teachers' efforts in implementing learner-centered teaching. First, teachers have students engaged and interested every single class. The development of skills is practically impossible without attention, effort, persistence, positive emotion, commitment, and voice. Engagement is a prerequisite for a productive learning experience. Engagement gives teachers the moment-to-moment feedback they need to determine how well their efforts to motivate students are working. High versus low engagement is telltale feedback about students' underlying motivation during the lesson.

Second, teachers give autonomy and responsibility to students for material they learn and their own learning in general. High autonomy becomes one of the factors contributing the satisfying learning experience. The following opinions are the opinions of one of the respondents.

"Sometimes I allow my students to learn the material they like by themselves, for example by asking them to go to the library, read and learn on their own. They can share with their friends and discuss it. I do this to improve their autonomy in learning and not rely too much on me. I am just trying to cultivate their learning autonomy."

Third, teachers use highly engaging core content that meets the needs of the students, meaning that material is meaningful for the students. As we know that content is not the only focus of the teacher in implementing learner-centered teaching effectively. However, the highly engaging core content that meets the students' need will help the teacher to create an effective learner-centered teaching. Therefore, it is a need for every teacher to select an appropriate content based on various students' needs and characteristics.

Fourth, teachers give feedback to help students to improve. Teachers tried to integrate formative assessment within the learning process as much as possible. By doing this under-prepared and non-traditional students benefit from continual feedback and encouragement. Feedback plays a very important role on students learning. Through this feedback, a student can know the extent to which the material teacher has taught can be mastered. With that feedback, students can also 
cope with their own ability, or in other words as a corrective means of student learning progress.

Fifth, teachers help students to use resources responsibly. With everything available on the Web, information is easily obtained, so teachers' effort is to help them to how to paraphrase and cite properly. The following is the opinions of one of the respondents.

"With increasingly sophisticated technology, actually it greatly facilitates students to obtain information. However, as a teacher, we have to be careful because not all sources of information on the internet can be used by students. We must cultivate a positive habit that keeps them away from plagiarism. One way is to teach them how to quote and paraphrase the statement well from the internet, not just copy and paste".

The last is teachers utilize multiple teaching techniques appropriate for student learning goals such as small group discussion, answered question, and review content. Certain teaching methods are only suitable for students who have a particular learning style. If teachers use only one method, it is certain that students who have a particular learning style will become bored and cannot achieve the expected learning objectives. Put this example, if the teacher teaches by lecture method using instructional media in the form of power point presentation, then the student that will fit is the student with the audio-visual learning style. Therefore, various teaching methods are expected to be implemented in learnercentered teaching in order to accommodate various learners' characteristics and needs including their learning style. Besides, the use of a variety of teaching methods in accordance with the learning materials will make students have a deeper understanding of the material. They are not only as memorizers, but most likely will be able to apply their knowledge to real life. Through it students will have a more meaningful learning experience. Moreover, students will be helped to express their feelings as teachers use a variety of teaching methods. Expressing feelings will be able to do in various ways, as a result of the use of varied teaching methods. This will make students volunteer to learn and be eager to participate actively. They will think independently, and unconsciously they have been drowned and actively involved in teaching learner process. Through this interaction, effective learnercentered teaching can be achieved.

\section{Teachers' role in learner-centered teaching}

The second part done in this study is investigating teachers' role in learner-centered teaching. Having interview with two English teachers, it is found several findings. In learner-centered teaching, teachers' role is now as guides, facilitator, and coaches. Teachers should act their role in:

1) Providing various ways and forms to access learning materials

In learner centered teaching, teachers should be able to provide various ways and forms to access learning materials because students have different ability. Certain ways of teaching are only suitable for certain learning materials, while there are many materials to be taught to students. If teachers only provide one way, it tends to be bored and students are not interested in participating actively. For example, teacher can provide task to the students and ask them to do it in pair or group. By doing this, student often understands what his friends are saying, rather than the teacher, the usual way of learning used by students is more easily captured by other students. So, utilizing students' assistance can improve understanding and mastery of learning materials.

2) Acting as a facilitator who helps students in learning materials

Currently, the role of teachers in the classroom is more emphasized as a learning facilitator. Teachers are no longer the only source of information for learners. This is confirmed in the implementation of the 2013 Curriculum, because in fact, teachers are often the main source of information and learning tends to focus on the teacher. The emphasis that teachers now play as 
facilitators is meant to make the class more lively and passionate. In learner-centered teaching, teachers can act as facilitators. They are in charge of facilitating the learning that takes place in the learners themselves, so that they gain a real and authentic learning experience. By facilitating learning, it means the teacher seeks to invite and bring all the learners who are in his class to participate.

Facilitating learning is not an easy task if teachers do not have enough understanding of educational psychology and various learning theories following innovative models and methods for teaching. The facilitation of learning means that all learners with all the uniqueness and characteristics of each should be able to be stimulated by the teacher to follow the ongoing learning. This is important because of the desire and motivation that arises from within the students will make them more in understanding something that are being taught in the classroom. The following is the opinion from one of the respondents regarding teachers' role as facilitator.

"As facilitators teachers are required to have the ability to communicate and interact with students. This is very important since effective communication skills can make it easier for students to catch messages so they can improve their learning motivation".

Besides, the emphasis of teacher as facilitator is seen from the following statement stated by Cooper (1994):

"Now, a teacher is not a source of knowledge, but a facilitator. These days, an instructor is also considered as an inspirer who is supposed to inspire learners by creating a favorable environment. Now as it is believed that knowledge is constructed by learners from experience, the instructor needs to be a guide on the side, rather than a sage on the stage. If teaching is a professional job, facilitating is the role of the teacher."
"Teachers act as facilitators, helpers or consultants." (Knowles, 1975)

This is also in line with what Voller (1997) stated as follows:

"The language teacher may act as a facilitator who initiates and supports decision-making processes, a counselor who responds to the ongoing needs of individuals, and a resource who makes his or her knowledge and expertise available to the learners when it is needed."

3) Providing support to students in active learning to improve students' skills in mastering the knowledge According to Higgs (1988), during the learning process, in order to help the student learn how to learn independently and effectively, the teacher play the role of a manager who creates a supportive and stimulating learning environment, who is available as a resource person, who challenges learners to achieve their potential and who helps learners to become aware of institutional requirements and expectations associated with the discipline in which they are studying. This means that it is the teachers themselves who ultimately determine the success of learnercentered teaching. The following is the opinion from one of the respondents:

"There are many ways that can be done to create good teaching, but the teacher is still the one who determines the success of learner-centered learning. Although the focus of this learning is on the students, but they cannot do it by themselves, the teacher must play its role in providing support, encouraging its students to be actively involved in classroom activities".

4) Increase motivation and enthusiasm of the students to promote learning and improve their ability to learn independently Teachers play important roles in creating an environment that fosters students' learning, accommodates different learning styles, and motivate students to accept responsibility 
for learning. Teachers' role is also in designing activities in which students interact with the material, the teacher and each other. It is seen from the result of the interview as follows:

"we are now as guides, coaches, and facilitator. As the teachers, we play role in creating an environment that fosters students' learning, accommodates different learning styles, and motivate students to accept responsibility for learning. We have to be able to facilitate active learning. We have to provide various ways, activities and forms to access learning. Ya, we have to prepare everything very well, because learnercentered teaching does not mean that it is without teacher, but teacher is the one that play a big role to create an effective class."

\section{CONCLUSION}

Learner-centered teaching is not learning without teachers (Lengkanawati in Bernard \& Li, 2016, p. 146) but it starts with the teachers. Teachers play a very important role and do many efforts to conduct an effective learnercentered teaching. Being a learner-centered teacher should be every teacher's goal, but it is not necessary or practical to be learnercentered on every component. Teachers should not expect their courses ever to be at the highest standard in all categories with every component.

This study has investigated several issues related to teachers' efforts and teachers' role in learner-centered teaching. Then, the findings, as a set of conclusions, are drawn as follows:

1. Several efforts done by teachers in learner-centered teaching are first, teachers are not a conveyor of information. It is the students who do the hard messy work of learning, they are not passive recipients of knowledge. Second, teachers give autonomy and responsibility to students for material they learn and their own learning in general. Third, teachers use highly engaging core content that meets the needs of the students. Fourth, teachers give feedback to help students to improve. Last, teachers utilize multiple teaching techniques appropriate for student learning goals.

2. Several roles of teachers in learnercentered teaching are as guides, facilitator and coaches. Teachers also play an important role in creating an environment that fosters students' learning, accommodates different learning styles, and motivates students to accept responsibility for learning.

\section{REFERENCES}

Brown, H. D. (2001). Teaching by principles: An interactive approach to language pedagogy. New York: a Pearson education company.

Benson, P. (2003). Learner autonomy in the classroom. In D. Nunan (Ed.). Practical English language teaching. New York: McGraw Hill.

Creswell, J. W. (1994). Research design: Qualitative, quantitative, and mixed methods approaches. Los Angeles: Sage Publications.

Ellis, R. (1994). The study of second language acquisition. New York: Oxford University Press.

Higgs, J. (1988). Planning learning experiences to promote autonomous learning. In D. Boud (Ed.), Developing student autonomy in learning (2nd ed.) (pp. 40-58). London: Kogan.

Knowles, M. (1975). Self-directed learning: A guide for learners and teachers. Chicago: Association Press.

Marshall \& Rossman. (2007). Designing qualitative research. London: Sage Publication.

Nunan, D. (1988). Learner-centred curriculum: A study in second language teaching. Cambridge: Cambridge University Press.

Thanh, H. P. (2010). Implementing a student-centered learning approach at Vietnamese higher education institutions: Barriers under layers of Casual Layered Analysis (CLA). Journal of Future Studies, 15(1), 21-38.

Tudor, I. (1993). Teachers' role in the learner-centered classroom. Oxford: Oxford University Press.

Voller, P. (1997). Does the teacher have a role in autonomous language learning? In P. Benson, \& P. Voller (Eds.), Autonomy and independence in language learning. London: Longman

Weimer, M. (2013). Learner-centered teaching. San Francisco: Jossey-Bass. 
Endang Darsih

Learner-centered teaching: What makes it effective 